\title{
Proposed Design of Walk-Through Gate (WTG): Mitigating the Effect of COVID-19
}

\author{
Saddam Hussain ${ }^{1, *(\mathbb{D}}$, Muhammad Jehanzeb Masud Cheema ${ }^{2}(0)$, Saad Motahhir ${ }^{3}{ }^{(1)}$, \\ Muhammad Mazhar Iqbal ${ }^{4}$, Arfan Arshad ${ }^{1}$ (D), Muhammad Sohail Waqas ${ }^{5}$ (D), \\ Muhammad Usman Khalid ${ }^{6}$ and Saba Malik ${ }^{7}$ (D) \\ 1 Department of Irrigation and Drainage, University of Agriculture, Faisalabad 38000, Pakistan; \\ 2012ag3729@uaf.edu.pk \\ 2 Faculty of Agricultural Engineering and Technology, PMAS-Arid Agriculture University, Rawalpindi 46000, \\ Pakistan; mjm.cheema@uaar.edu.pk \\ 3 Engineering, Systems and Applications Laboratory, ENSA, SMBA University, Fez 30050, Morocco; \\ saad.motahhir@usmba.ac.ma \\ 4 Department of Water Resource Engineering and Management, National University of Sciences and \\ Technology (NUST), Islamabad 45710, Pakistan; maziqbal@mce.nust.edu.pk \\ 5 Soil Conservation Group, Agriculture Department (Field Wing), Government of the Punjab, \\ Rawalpindi 46000, Pakistan; sohailwaqasrana@gmail.com \\ 6 Program Management Unit, Agriculture Department, Government of the Punjab, Rawalpindi 46000, \\ Pakistan; usman.engr87@gmail.com \\ 7 Department of Zoology, Wildlife, and Fisheries, University of Agriculture Faisalabad, Faisalabad 38000, \\ Pakistan; sabam3651@gmail.com \\ * Correspondence: Saddam.wahla@uaf.edu.pk; Tel.: +92-324-7712366
}

Received: 14 August 2020; Accepted: 15 September 2020; Published: 21 September 2020

\begin{abstract}
The world is facing a new challenge to overcome the pandemic disease of Coronavirus (COVID-19). An outbreak of COVID-19 to more than 213 countries and territories caused damage to the economy of every country. The proper vaccine to combat this pandemic disease is not invented yet. Due to the lockdown situation, there is a shortage of daily used products globally. To overcome the issue of food shortage and economic survival, the world has to ease the lockdown rules and become operational with the precautionary measures. COVID-19 has a fast transmission rate, therefore, while living with COVID-19, breaking the fast transmission chain of COVID-19 is the only vital solution. Furthermore, there is a dire need to disinfect every individual and his luggage at the entrance of every shopping mall, hospital, public and private institutions, bus stops, metro stations, and railway stations. Hence, the proposed walk-through gate (WTG) with different sensors, i.e., infrared thermal camera, UV disinfectant sensor, disinfectant spraying system, touch-less hand sanitizer, and box having a face mask with a dustbin to discard the previous mask can provide an effective and efficient relief. The world cannot stop working and cannot survive for more than 3-6 months in a lockdown, hence the proposed idea is to install the disinfectant automated spraying WTG with a security walk-through gate at every possible entrance to conform living with the COVID-19 disease such as many other diseases. Breaking the transmission chain is the only solution to win the battle against COVID-19 until an effective vaccine invention.
\end{abstract}

Keywords: pandemic; sustainable society; walk-through gate; disinfectant spray; hot air

\section{Introduction}

The world has no proper vaccine to deal permanently with the virus disease and vaccines are only invented to deal with a bacterial disease. Meanwhile, another virus disease outbreak takes place 
in late December 2019, in Wuhan city of China and is named as a novel coronavirus [1,2]. Wuhan city is badly affected by this disease and China introduced a lockdown of the whole Wuhan city and used all its resources to disinfect every public place, i.e., roads, bus stops, railway stations, hospitals, buildings, food markets, etc. [3-6]. The Chinese government used local and advanced technology, i.e., a walk behind spraying system and unmanned aerial spraying systems, respectively [7-10]. Meanwhile, citizens of other countries have started to leave China and return back to their home countries. Moreover, the other countries were not fully prepared to deal with their residents returning from the COVID-19 epicenter country. There is a lack of appropriate arrangement at the airport in every country due to the novel nature of this viral disease. The COVID-19 infected people do not show symptoms in the early days (2-14) and they can easily bypass the airport scanning system, but later on, those individuals went on to infect others and their relatives. Due to this reason, this viral disease affects every developed and developing country in the world in a very short duration.

The COVID-19 disease has two major problems: (1) Not showing symptoms in the initial 2 to 14 days, and (2) the virus can stay alive (from 4-5 h to 6-9 days) on its host depending upon its type, i.e., wood, glass, metal handle door, air, etc. [11-14]. Therefore, this pandemic disease spread as a fast diffusion reaction and within four months, it trapped the whole world, since December 2019 and top 15 highly affected countries with COVID-19 are shown in Figure 1. It reached more than 213 countries and territories around the globe [1,15-20]. Furthermore, some scholars [18,21] expected that it can infect more than 100 million people in the world if the vaccine is not invented in the next 6 to 12 months.

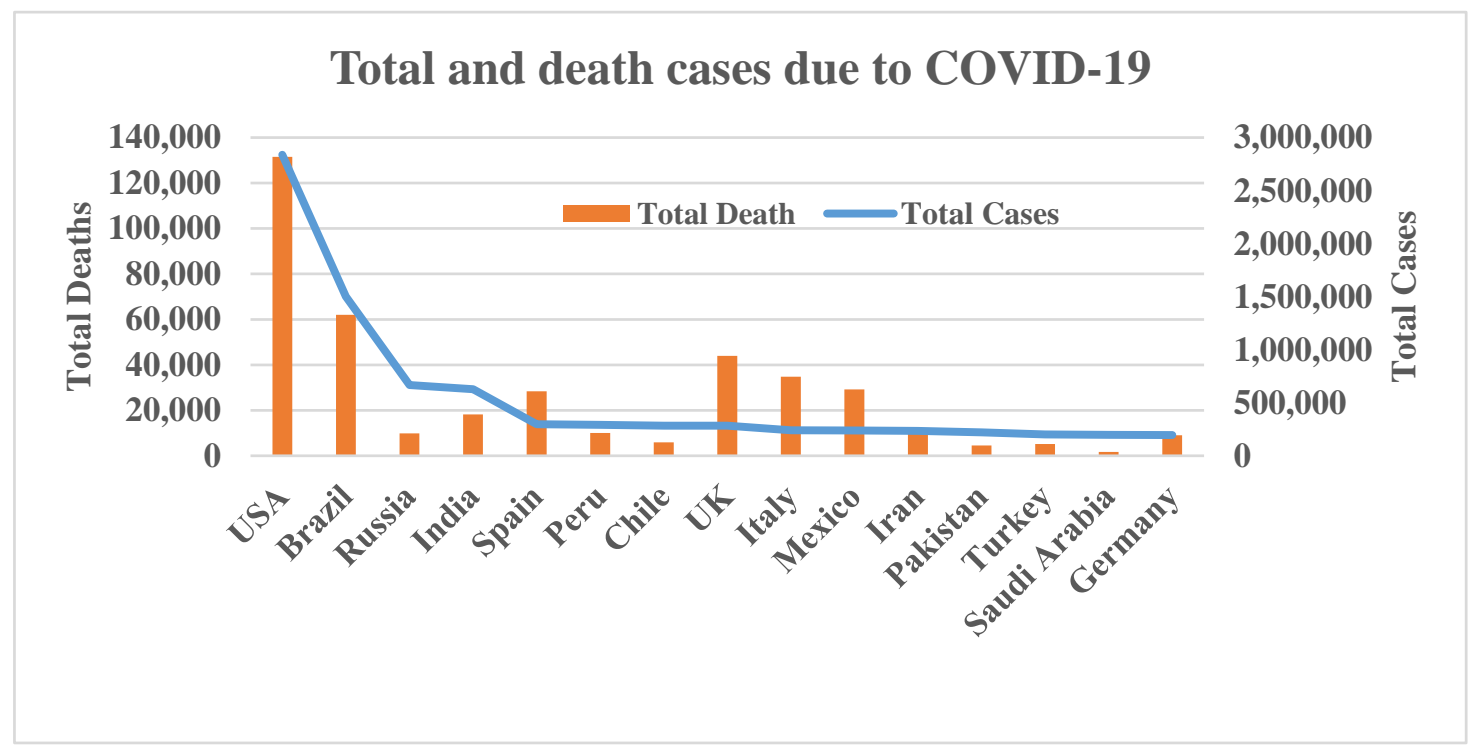

Figure 1. Total and death cases in the top 15 highly affected countries with COVID-19. Source: https://www.worldometers.info/coronavirus/\#countries; Assessed on: July 03, 2020.

Meanwhile, due to the lockdown situation [22], the world development process is affected badly and all industrial activities are shut down, which affects every country's stock market and the world faces a loss of more than 17 trillion dollars [23,24]. Therefore, it is expected that more than 1 billion people will be affected due to inflation and poverty in the world due to COVID-19.

Keeping in view the above situation, a lockdown is not the suitable solution to deal with this pandemic situation. In most countries, there is a very strict lockdown but the pandemic situation is getting worse day-by-day [25-27]. The world cannot afford a lockdown of more than one year and some countries (developing and underdeveloped) cannot afford more than six months, otherwise people will start dying due to poverty and shortage of food. Hence, the suicide rate due to hunger and poverty will be increased in the world [28,29].

The WHO issued guidelines related to the disinfectant spraying systems on 15 May 2020 for the cleaning of surfaces to remove the pathogens from contaminated surfaces. The WHO stated 
that a direct contact of the recommended disinfectant spray disinfects the surfaces and inactivates the germicidal properties or mode of action of several disinfections [30]. Moreover, for an effective application of the disinfectant, its duration and concentration are critical to disinfect the surfaces effectively. Hence, the application of chemical solutions, i.e., alcohol or chlorine would be applied to kill the microorganisms [31-33]. The WHO recommended that to disinfect the surfaces, the disinfectant solution must be prepared according to the suggestions of the manufacturer, i.e., the spraying volume concentration and moving person contact time. Over or under concentration of the disinfectant can reduce its effectiveness [8]. Moreover, a high concentration of the disinfectant may increase the chemical exposure of consumers and can damage the surfaces [34]. Therefore, the optimum and recommended concentration of the disinfectant is useful to disinfect the things at entrance and exit locations. Moreover, researchers also developed a wristwatch to disinfect the hand continuously [35].

After the strategy of lockdown failed and the stroke of poverty, countries will have to open the borders and start trading with each other but the problem of the pandemic disease is still ongoing. Therefore, to overcome the problems of pandemic disease COVID-19 that include (i) fast spreading rate (i.e., through touching, sneezing, handshaking, and breathing in infected air, etc.), (ii) not showing symptoms in the infected person in the initial 2 to 14 days, (iii) the virus can stay alive 6 to 9 days according to the host surface (i.e., air, wood, metal, and glass), (iv) no proper vaccine is available to cure the infected person, and (v) protecting the world from entering dire poverty and suicides, there is one option left to start living in this world with precautionary measures of COVID-19 until the invention of the proper vaccine.

The proposed precautionary measure is the design of advanced WTG having an automated spraying system with an additional RGB thermal sensor, touchless hand sanitizer, and mask box. In the mask box, every single mask will be sealed properly in degradable packing to minimize the chance of infection.

\section{Design of the Proposed Equipment}

\subsection{Proposed WTG Design}

Key parameters of the WTG are (1) dustbin to discard the used/infected mask or tissues, etc., (2) touchless hand sanitizer in which the person just proceeds his hand under the sanitizer box and the sanitizer drop will come out after sensing the person's hand, (3) in the touchless face-mask box, every mask is separately sealed in a degradable material and the person puts his hand in front of the sensor and one mask will come out, (4) the ON/OFF sensor is attached at every shower to turn ON/OFF the shower when a person comes in front of it or moves away, (5) it indicates the shower to spray the disinfectant in the mist form, (6) it indicates the UV disinfectant sensor to disinfect the luggage or metal materials, (7) there is an RGB thermal camera to scan the human body temperature while entering into the WTG and if the body temperature is higher than the permissible limit, an alarm bell will start beeping to take the necessary action for the specific person, (8) it indicates that the shower is OFF because the person is not in contact with the sensor, and (9) the alarm bell will start beeping if the human body temperature is higher than the permissible limit $\left(36.1\right.$ to $\left.37.5^{\circ} \mathrm{C}\right)$ and the temperature range can be set according to the requirement, (10) it indicates the control panel, which controls all the sensors (ON/OFF), working of showers, regulating the power, and spraying supply in the system. (11) At this point, an electric motor is attached to provide a pressurized supply of the disinfectant spray to every shower when it receives the command to turn "ON" the shower for spraying. At point (12), the spraying tank in which the disinfectant spray is available provides a regular supply to the spraying showers as shown in Figure 2. 


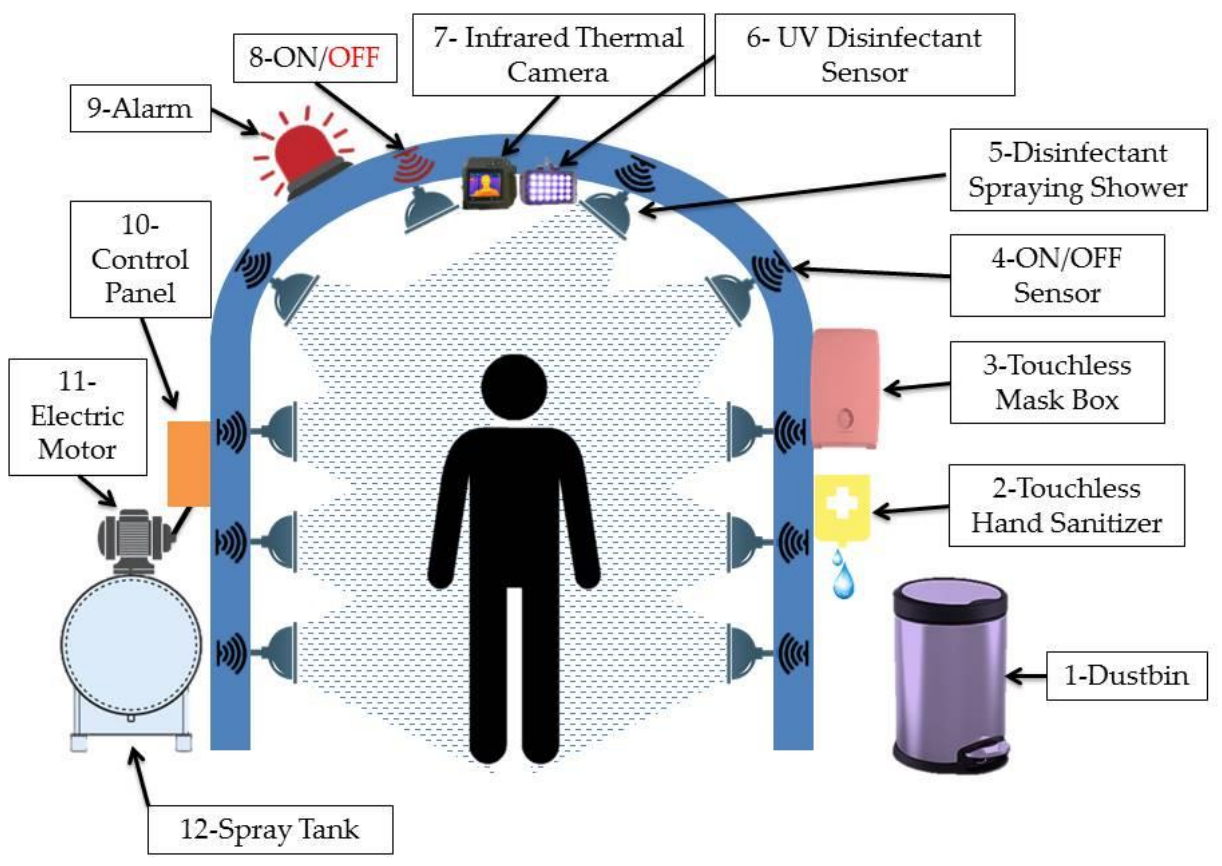

Figure 2. Showing the proposed automated disinfectant spraying walk-through gate.

The alarm (9) can also start beeping when the mask box or hand sanitizer box is empty and there is a need to change or refill that box again.

When a person moves through the WTG and the disinfectant spray is applied to his body and clothes, a fine mist of spray will attach to his body as well as on the clothes. Moreover, due to the disinfectant spray, clothes become smelly. Due to the moist body and clothes, there is a chance that any virus from the air can attach to his body parts or clothes. To overcome this issue, minimize the chance of infection, and to vanish off the bad smell from the clothes, a fragranced hot air mechanism (Figure 3) is also installed on the other side of the gate.

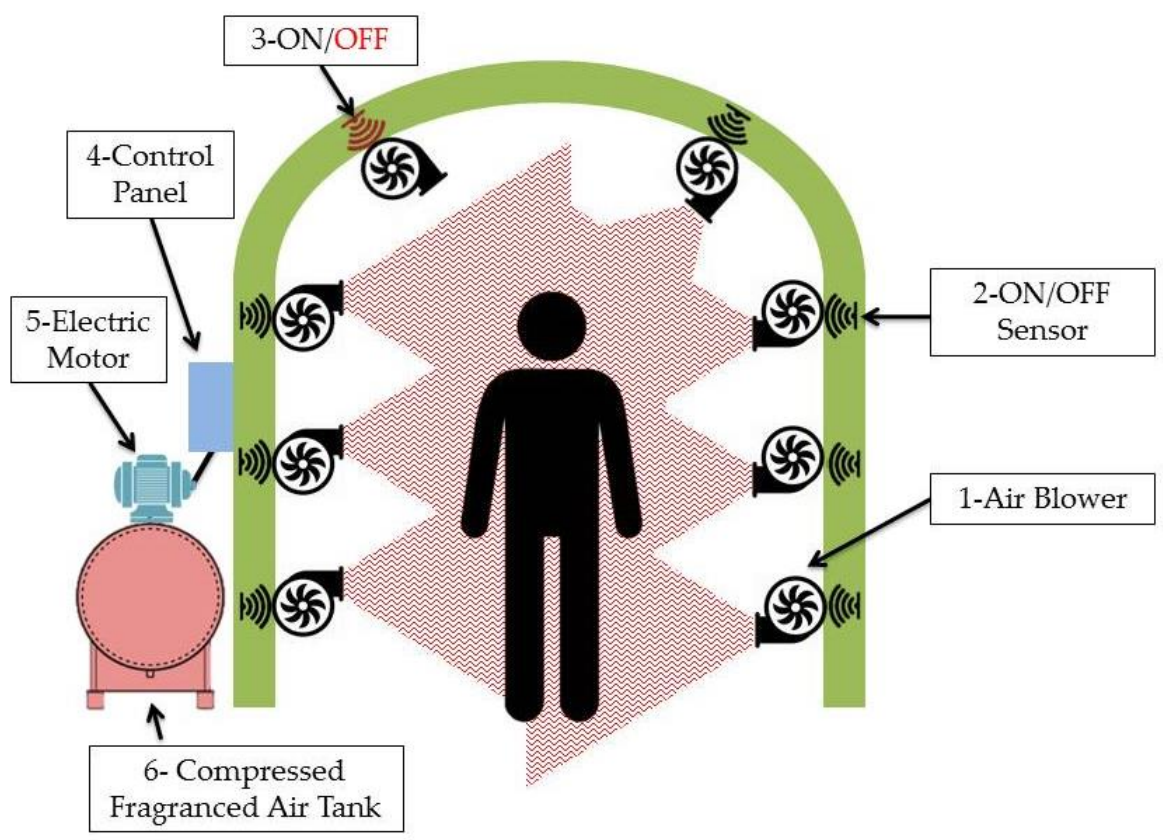

Figure 3. Showing the next section of the gate with a fragranced hot air mechanism. 


\subsection{Proposed Design of Fragranced Hot Air}

The fragranced hot air mechanism includes (1) an air blower for supplying the fragranced hot air, at point (2), the ON/OFF sensor is attached for the sustainable use of resources and turning ON/OFF the air blower only when a person is in contact with those sensors. Point (3) shows that the air blower is OFF because a moving person is not in contact with that sensor, and point (4) indicates the control panel of the next section of the WTG. At point (5), the location motor is installed to provide pressurized hot air to the blowers when receiving the command to turn ON the air blower. Furthermore, at point (6), the air compressor is connected with the system to provide the mixed fragranced hot air to the person while moving through this WTG.

The fragranced hot air will be administered to every moving person when a person comes in front of the ON/OFF sensor of the air blower, then the fragranced hot air will dry his body, clothes, and a pleasant fragrance will come from his dress.

It also depends on the developer to install this modification or just adopt the WTG design up to the Figure 2 level only.

\section{Cost Effectiveness and Applicability}

The development of the proposed WTG requires sensors, assembly parts, and accessories that are commonly available in the local and international markets at very affordable price. Under-developed countries can buy the required sensors from an online website source (https://www.amazon.com/). There is no hard and fast rule during the selection of materials to develop the proposed WTG. The developers can use locally available materials, i.e., plastic, iron roads, iron sheets, and may be any locally available wood. Therefore, due to the flexibility in the selection of materials, that makes the WTG cost effective for every developing country.

Moreover, the Pakistan Medical Association (PMA) [36] has advised the government to make sure that public and private sectors install WTG at the point of entrance and exit. Furthermore, the administration of Capital Development authority (CDA) and Islamabad Capital Territory (ICT) have installed more than twenty (20) WTGs at different entrances and exit locations of the capital city Islamabad, Pakistan to limit the spread of the virus. The CDA official declared that the price for the tunnel (six meter long) WTG is about $\$ 1220$ and for the smaller one, the price can be about $\$ 610$. Keeping in view the COVID-19 pandemic situation in the world, the WTG disinfectant gate cost is very nominal and affordable for developing and underdeveloped nations. Moreover, the researcher also developed a cost effective and easy to build portable ventilator for COVID-19 patients [37].

\section{Conclusions}

COVID-19 is a fast transmission viral disease and no vaccine is invented yet to combat this pandemic disease. Most of the countries in the world lockdown their cities or a whole country to minimize the transmission of COVID-19. Due to the strict lockdown, many other problems take place, i.e., shortage of food, unemployment, failure of the health care system, the country's badly affected economy, and the stock market. If countries continue the lockdown situation, maybe more people will die due to the poverty than the COVID-19 pandemic disease. Moreover, developed and under developing countries cannot bare lockdown situations of 6-12 and 3-6 months, respectively. Therefore, countries have to loosen the lockdown rules and start living with the COVID-19 disease as we are living with many other diseases with precautionary measures. The idea is to develop the recommend disinfectant WTG and install it at every entrance (i.e., school, university, shopping mall, hospitals, playing grounds, etc.) with a security walk-through gate or disinfectant WTG that can be embedded within the security gate. Such a disinfectant WTG is more necessary than the security walk through the gate because the virus cannot be detected with any sensor and nothing is invented to check the clothes and luggage while entering into any organization or institution. If a person is virus-free (by checking his body temperature or doing the COVID-19 test), it might still be possible that, he/she is 
carrying a virus through his clothes and luggage. Therefore, carrying a virus while entering into any country or sensitive organization (army centers) is a future threat for every country. By installing the advanced disinfectant WTG at every possible entrance, that can help each country to disinfect the person's body, clothes, and luggage frequently and break the chain of the fast-spreading pandemic disease. The Authors recommend such an advanced type of WTG to break the chain of the COVID-19 pandemic disease.

Author Contributions: Conceptualization, S.H. and M.S.W.; validation, M.J.M.C., S.M. (Saad Motahhir), M.M.I., A.A., M.S.W., M.U.K., and S.M. (Saba Malik); formal analysis, S.H., M.J.M.C., and M.S.W.; investigation, S.H., M.J.M.C., S.M. (Saad Motahhir), A.A., M.S.W., and S.M. (Saba Malik); resources, S.H., M.J.M.C., S.M. (Saad Motahhir), M.M.I., and S.M. (Saba Malik); data curation, S.H., M.J.M.C., S.M. (Saad Motahhir), A.A., and M.S.W.; writing-original draft preparation, S.H.; writing-review and editing, S.H., M.J.M.C., S.M. (Saad Motahhir), M.M.I., A.A., M.S.W., M.U.K., and S.M. (Saba Malik); visualization, S.H., M.J.M.C., S.M. (Saad Motahhir), M.S.W., and S.M. (Saba Malik); supervision, S.H., M.J.M.C., S.M. (Saad Motahhir), and M.M.I.; project administration, S.H., M.J.M.C., S.M. (Saad Motahhir), M.M.I., A.A., M.S.W., M.U.K., and S.M. (Saba Malik). All authors have read and agreed to the published version of the manuscript.

Funding: This research received no external funding.

Conflicts of Interest: The authors declare that they have no conflict of interest.

\section{References}

1. Heymann, D.L.; Shindo, N. COVID-19: What is next for public health? Lancet 2020, 395, 542-545. [CrossRef]

2. Koonin, L.M. Novel coronavirus disease (COVID-19) outbreak: Now is the time to refresh pandemic plans. J. Bus. Contin. Emerg. Plan. 2020, 13, 1-15.

3. World Health Organization. Laboratory Testing for Coronavirus Disease 2019 (COVID-19) in Suspected Human Cases: Interim Guidance, 2 March 2020; World Health Organization: Geneva, Switzerland, 2020.

4. Shi, H.; Han, X.; Jiang, N.; Cao, Y.; Alwalid, O.; Gu, J.; Fan, Y.; Zheng, C. Radiological findings from 81 patients with COVID-19 pneumonia in Wuhan, China: A descriptive study. Lancet Infect. Dis. 2020, 20, 425-434. [CrossRef]

5. Tian, S.; Hu, N.; Lou, J.; Chen, K.; Kang, X.; Xiang, Z.; Chen, H.; Wang, D.; Liu, N.; Liu, D.; et al. Characteristics of COVID-19 infection in Beijing. J. Infect. 2020, 80, 401-406. [CrossRef]

6. Wong, J.; Goh, Q.Y.; Tan, Z.; Lie, S.A.; Tay, Y.C.; Ng, S.Y.; Soh, C.R. Preparing for a COVID-19 pandemic: A review of operating room outbreak response measures in a large tertiary hospital in Singapore. Can. J. Anesth. 2020, 67, 1-14. [CrossRef]

7. He, X. Rapid development of unmanned aerial vehicles (UAV) for plant protection and application technology in China. Outlooks Pest Manag. 2018, 29, 162-167. [CrossRef]

8. Hussain, S.; Masud Cheema, M.J.; Arshad, M.; Ahmad, A.; Latif, M.A.; Ashraf, S.; Ahmad, S. Spray uniformity testing of unmanned aerial spraying system for precise agro-chemical applications. Pak. J. Agric. Sci. 2019, 56, 897-903.

9. Jones, T. International Commercial Drone Regulation and Drone Delivery Services; RAND: Santa Monica, CA, USA, 2017.

10. Martinez-Guanter, J.; Agüera, P.; Agüera, J.; Pérez-Ruiz, M. Spray and economics assessment of a UAV-based ultra-low-volume application in olive and citrus orchards. Precis. Agric. 2020, 21, 226-243. [CrossRef]

11. Xu, B.; Kraemer, M.U.; Gutierrez, B.; Mekaru, S.; Sewalk, K.; Loskill, A.; Wang, L.; Cohn, E.; Hill, S.; Zarebski, A. Open access epidemiological data from the COVID-19 outbreak. Lancet Infect. Dis. 2020, 20, 534. [CrossRef]

12. You, C.; Deng, Y.; Hu, W.; Sun, J.; Lin, Q.; Zhou, F.; Pang, C.H.; Zhang, Y.; Chen, Z.; Zhou, X.-H. Estimation of the Time-Varying Reproduction Number of COVID-19 Outbreak in China. Int. J. Hyg. Environ. Health 2020, 228, 113555. [CrossRef]

13. Zhou, F.; Yu, T.; Du, R.; Fan, G.; Liu, Y.; Liu, Z.; Xiang, J.; Wang, Y.; Song, B.; Gu, X.; et al. Clinical course and risk factors for mortality of adult inpatients with COVID-19 in Wuhan, China: A retrospective cohort study. Lancet 2020, 395, 1054-1062. [CrossRef]

14. Zu, Z.Y.; Jiang, M.D.; Xu, P.P.; Chen, W.; Ni, Q.Q.; Lu, G.M.; Zhang, L.J. Coronavirus disease 2019 (COVID-19): A perspective from China. Radiology 2020, 296, 200490. [CrossRef] [PubMed] 
15. Anderson, R.M.; Heesterbeek, H.; Klinkenberg, D.; Hollingsworth, T.D. How will country-based mitigation measures influence the course of the COVID-19 epidemic? Lancet 2020, 395, 931-934. [CrossRef]

16. Burki, T. Outbreak of coronavirus disease 2019. Lancet Infect. Dis. 2020, 20, 292-293. [CrossRef]

17. Calisher, C.; Carroll, D.; Corley, R.B.; Daszak, P.; Drosten, C.; Enjuanes, L.; Farrar, J.; Field, H.; Golding, J.; Gorbalenya, A.; et al. Statement in support of the scientists, public health professionals, and medical professionals of China combatting COVID-19. Lancet 2020, 395, e42-e43. [CrossRef]

18. World Health Organization. Coronavirus Disease 2019 (COVID-19): Situation Report, 51; World Health Organization: Geneva, Switzerland, 2020.

19. World Health Organization. Coronavirus Disease 2019 (COVID-19): Situation Report, 72; World Health Organization: Geneva, Switzerland, 2020.

20. Cascella, M.; Rajnik, M.; Cuomo, A.; Dulebohn, S.C.; Di Napoli, R. Features, evaluation and treatment coronavirus (COVID-19). In Statpearls [Internet]; StatPearls Publishing: Treasure Island, FL, USA, 2020.

21. World Health Organization. Coronavirus Disease 2019 (COVID-19): Situation Report, 67; World Health Organization: Geneva, Switzerland, 2020.

22. Zhao, J.; Rudd, A.; Liu, R. Challenges and potential solutions of stroke care during the coronavirus disease 2019 (COVID-19) outbreak. Stroke 2020, 51, 1356-1357. [CrossRef]

23. Shalev-Shwartz, S.; Shashua, A. Can We Contain Covid-19 without Locking-Down the Economy? Center for Brains, Minds and Machines (CBMM): Cambridge, MA, USA, 2020.

24. Jenkins, C. COVID-19: Look after people, not profits. Green Left Weekly 2020, 1257, 9.

25. Remuzzi, A.; Remuzzi, G. COVID-19 and Italy: What next? Lancet 2020, 395, 1225-1228. [CrossRef]

26. Jiang, S.; Xia, S.; Ying, T.; Lu, L. A novel coronavirus (2019-nCoV) causing pneumonia-associated respiratory syndrome. Cell. Mol. Immunol. 2020, 17, 554. [CrossRef]

27. Zaman, C.; Meunier, B. Efficiency and Effectiveness of Measures to Combat the Coronavirus in Selected Countries. 2020. Available online: https://papers.ssrn.com/sol3/papers.cfm?abstract_id=3561616 (accessed on 21 September 2020).

28. Gunnell, D.; Biddle, L. Suicide and the Media: Reporting Could Cost Lives; British Medical Journal Publishing Group: London, UK, 2020.

29. Lersch, K.M. Exploring the geography of suicide threats and suicide attempts: An application of Risk Terrain Modeling. Soc. Sci. Med. 2020, 249, 112860. [CrossRef]

30. World Health Organization. Cleaning and Disinfection of Environmental Surfaces in the Context of COVID-19: Interim Guidance, 15 May 2020; World Health Organization: Geneva, Switzerland, 2020.

31. Iqbal, M.M.; Abid, I.; Hussain, S.; Shahzad, N.; Waqas, M.S.; Iqbal, M.J. The effects of regional climatic condition on the spread of COVID-19 at global scale. Sci. Total Environ. 2020, 739, 140101. [CrossRef] [PubMed]

32. Zhang, Z.; Arshad, A.; Zhang, C.; Hussain, S.; Li, W. Unprecedented temporary reduction in global air pollution associated with COVID-19 forced confinement: A continental and city scale analysis. Remote Sens. 2020, 12, 2420. [CrossRef]

33. Arshad, A.; Hussain, S.; Saleem, F.; Shafeeque, M.; Khan, S.N.; Waqas, M.S. Unprecedented Reduction in Airborne Aerosol Particles and Nitrogen Dioxide Level in Response to COVID-19 Pandemic Lockdown over the Indo-Pak. Region 2; Bio-Techne: Minneapolis, MN, USA, 2020.

34. World Health Organization. Coronavirus Disease (COVID-19), Situation Report-115, Data as Received by WHO from National Authorities by 10:00 CEST, 14 May 2020; World Health Organization: Geneva, Switzerland, 2020.

35. El Majid, B.; Motahhir, S.; El Hammoumi, A.; Lebbadi, A.; El Ghzizal, A. Preliminary design of a smart wristband disinfectant to help in covid-19 fight. Inventions 2020, 5, 32. [CrossRef]

36. Junaidi, I. More Walk-Through Gates Could Help Prevent Spread of Coronavirus: Experts. 2020. Available online: https://www.dawn.com/news/1547605/more-walk-through-gates-could-help-preventspread-of-coronavirus-experts (accessed on 9 April 2020).

37. El Majid, B.; El Hammoumi, A.; Motahhir, S.; Lebbadi, A.; El Ghzizal, A. Preliminary design of an innovative, simple, and easy-to-build portable ventilator for COVID-19 patients. Euro-Mediterr. J. Environ. Integr. 2020, 5, 1-4. [CrossRef] [PubMed]

(C) 2020 by the authors. Licensee MDPI, Basel, Switzerland. This article is an open access article distributed under the terms and conditions of the Creative Commons Attribution (CC BY) license (http://creativecommons.org/licenses/by/4.0/). 